\title{
WHAT IS SO SPECIAL ABOUT EMERGING ECONOMY MULTINATIONAL ENTERPRISES?
}

\author{
ROBERTA RABELLOTTI (*) \\ Nota presentata dal m.e. Silvio Beretta \\ (Adunanza del 27 febbraio 2014)
}

SuNTO. - Il fenomeno delle imprese multinazionali dei Paesi emergenti (EMNEs) e della loro internazionalizzazione ha dato origine a un dibattito sulla idoneità delle teorie dell'impresa internazionale a dare conto di tale fenomeno. La letteratura si è occupata approfonditamente delle differenze fra le EMNEs e le AMNEs, cioè le imprese multinazionali dei Paesi avanzati. Il lavoro sintetizza e discute alcuni degli aspetti di tale argomento ai quali gli studiosi hanno prestato maggiore attenzione. Vengono discusse, in particolare, le differenze fra EMNEs e AMNEs per quanto riguarda tre aspetti di rilievo, particolarmente approfonditi in letteratura: 1) i vantaggi rispettivi specifici del Paese e quelli specifici dell'impresa; 2) le motivazioni dell'investimento all'estero; 3) le differenti modalità di ingresso nei mercati esteri. Si conclude che le EMNEs differiscono effettivamente dalle AMNEs, ma le differenze possono essere contingenti e transitorie.

ABSTRACT. - The phenomenon of Emerging Economy Multinational Enterprises (EMNEs) and their internationalization process have sparked the debate over the appropriateness of International Business theories to study EMNEs' internationalization processes. The literature has extensively investigated what distinguishes EMNEs from Advanced Country Multinational Enterprises (AMNEs). This review summarizes and discusses some of the issues that have mostly attracted scholarly debate in this research area. We discuss the specificities of EMNEs: how they differ from AMNEs with respect to three very important and well studied topics: first, country-specific and firm-specific advantages; second, motivations for investing abroad; and third, different modes of entry into foreign markets. We conclude that EMNEs do differ from AMNEs, although these differences may be contingent and transitory.

(*) Dipartimento di Scienze Politiche e Sociali Università degli Studi di Pavia, Italia. E-mail: roberta.rabellotti@unipv.it - Sito web: http://robertarabellotti.it 


\section{INTRODUCTION}

The unprecedented international expansion of firms from emerging economies is one of the most striking recent evolutions in the world Foreign Direct Investments (FDIs) landscape. FDI outflows from developing economies have reached the record level of $\$ 468$ billion in 2014, corresponding to $35 \%$ of global FDIs, up from $13 \%$ in 2007 (UNCTAD, 2015).

Emerging Economy Multinational Enterprises (EMNEs) are not a new phenomenon. More than thirty years ago, several contributions suggested that Multinationals Enterprises (MNEs) from developing countries possessed specific and distinctive features that distinguished them from MNEs based in developed countries (e.g. Kumar and McLeod, 1981; Lall and Chen, 1983). This first wave - from the 1960s until the early 1980s - involved mostly firms from Latin America expanding abroad, with investments driven mainly by market- and efficiency-seeking objectives (Andreff 2003). FDIs were directed mostly towards other developing countries, especially those characterised by smaller geographical, cultural, ethnic and institutional distance (Barnard 2008; Tolentino 1993). The most active EMNEs were often State-Owned Enterprises (SOEs) (Rasiah and Gammeltoft 2009).

During the second wave of investment in the 1980s, FDIs from emerging markets were more oriented at asset seeking, targeting both developed and developing countries. Asian MNEs, first from South Korea, Taiwan, Hong Kong, Singapore and then from Malaysia, Thailand, China, India and the Philippines dominated the scene, mostly expanding towards fast growing foreign markets, but they also invested for accessing cheap labour in other developing countries (Lall and Chen, 1983; UNCTAD 2005).

Since the 1990s, the features of FDIs from emerging countries have been distinctive compared to earlier waves of investments. In particular, the investing EMNEs are often privately owned, and Merger and Acquisition (M\&A) activity has increased. Although greenfield investments continue to be the dominant mode of entry, investments to acquire technology, brands, marketing and R\&D capabilities, distribution networks, managerial and organizational competencies are usually in the form of M\&A (Barnard 2008; Cantwell and Barnard 2008; Dunning and Wymbs 1999; Kumar 1998; Rasiah and Gammeltoft 2009; Rugman and Doh 2008). 
Due to their increasing importance in the global economic landscape, and their changing strategies over time, EMNEs have attracted increasing attention of researchers and policy makers and a lively scholarly debate has recently sparked about whether existing theories are appropriate to study EMNEs' internationalization processes. Several scholars have extensively investigated the distinctive features of EMNEs, comparing them to the characteristics of Advanced Country Multinational Enterprises (AMNEs) (Mathews 2002; Narula 2006; Ramamurti 2012).

This paper presents this debate (Section 2) and also aims at providing the reader with a general overview of the main contributions describing EMNEs' characteristics, and their distinctive features with respect to AMNEs. It focuses on two main dimensions. First, the ownership advantages possessed by EMNEs, which comprise CountrySpecific Advantages (CSAs), based on the specificities of the EMNE's home economy, and Firm-Specific Advantages (FSA) discussed in Section 3. Second, EMNEs' motivations for investing abroad, which differ depending on the host country characteristics, are investigated in Section 4. Section 5 concludes the paper.

\section{SetTing THE Debate}

There is not a wide agreement among scholars about the applicability of extant theories to explain the increasing presence of EMNEs. There are two clearly opposing views in the literature: "one is that EMNEs are a new species of MNEs that can be understood only with new theory (Mathews 2002); the other is that existing theory is quite adequate to explain EMNEs (Narula 2006)" (Ramamurti 2012: 41). Whether the on going debate will ever achieve a consensus is unclear. According to Ramamurti (2008), comparative case studies of EMNEs from numerous countries suggest that any attempts at generalization will necessarily be misleading since EMNEs are a heterogeneous group in terms of home countries, industries, competitive advantages, targeted markets and internationalization paths: "The evidence [does] not permit sweeping generalizations about EMNEs nor about how they are different from MNEs that came before, because the latter is also a beterogeneous group" (Ramamurti 2008: 1). Therefore, the real challenge is assessing which aspects of the existing theories are 
applicable and useful to understand EMNE strategies, motivations and advantages, and to identify aspects that require a new theoretical lens.

The most influential approach that has been applied to study the international activities of MNEs is the 'eclectic paradigm' proposed by Dunning (1981), according to which the firm's decision to expand its activities abroad via FDI, depends on three distinct advantages: a) Ownership - $O$ advantages, which is the firm's ownership of firm specific resources that can be exploited externally; b) Location - $L$ advantages, which depend on the characteristics of the host country; and c) Internalization - I advantages, which depend on the opportunity to internalize firm specific advantages rather than relying on the market through arm's length transactions. These three advantages constitute the so-called OLI (Ownership-Location-Internalization) framework, which, after successive refinements, has become mainstream in internationalization theory.

In his subsequent work, Dunning has extended this framework to account for the main changes in international markets, for example, the rise of alliance capitalism and the proliferation of firm networks during the 1990s (Dunning, 1995). Thus, the concept of O advantage has been extended to include the benefits accruing to firms from interacting with and sharing knowledge with other firms. In the context of I advantage, Dunning has suggested that alliances and networks of firms could be considered a distinct organizational mode which complements the hierarchical mode in the internalization view based on transaction cost theories. These proposals were prompted by the growing relevance of strategic asset-seeking motivations for investing abroad (Dunning, 1998). In his later works, Dunning (2006) acknowledges the importance of institutions as an essential component in the firm internationalization process, while Dunning and Lundan (2008) propose a formal distinction in the OLI paradigm between traditional asset advantages and institutional advantages. They claim that institutional advantages exert different influences on "the ways in which firms create new or utilise more effectively their existing resources, capabilities and markets" (Dunning and Lundan 2008: 582).

In light of the recent wave of EMNEs internationalization, the OLI framework has been criticized. According to the OLI framework (Dunning 1998), EMNEs must possess relevant ownership advantages to offset the disadvantages of competing abroad, whereas it seems that EMNEs are internationalizing to obtain the ownership advantages they 
lack (Mathews 2002). From this perspective, the OLI framework is seen as a static paradigm that takes account only of the pre-existing advantages in the FDI decision, and does not explain the opportunities for the development and evolution of firm capabilities over time, based on the accumulation of experience in international markets. The main criticisms come from the dynamic capabilities (Teece et al., 1997), and the asset-exploration approaches, which consider that firms internationalize in order to get access to necessary strategic resources and, thus, are motivated by "learning objectives that allow these firms to overcome the initial resource hurdles arising due to technological gaps and late mover disadvantages in international markets" (Aulakh 2007: 237). In this view, internationalization is a strategy aimed at strengthening the firm through the accumulation of previously unavailable resources.

Mathews (2002) proposes an alternative framework, inspired by the observation of a group of dynamic firms originating from the AsiaPacific region, described collectively as "Dragon Multinationals". The main point is that, in most cases, EMNEs (unlike AMNEs) do not possess huge domestic assets that can be exploited abroad and, in embarking on an outward orientation strategy, they form linkages (through joint ventures and other forms of collaboration in global value chains) with foreign companies to secure fast access to lacking resources. These global linkages can then be used to leverage the EMNEs' resources and particularly their cost advantages, to learn about new sources of competitive advantages and how to operate internationally. In contrast to the predictions of Dunning's OLI framework, the first phase of EMNEs formation is most likely to be spurred by asset-exploring rather than asset-exploiting motives. Also, in the early stages, this process is frequently linked to inward FDI activity in the home market ( $\mathrm{Li} 2007$; Luo and Tung 2007), which provides local firms with a unique chance to enter an established foreign production network and enhance their capabilities. In Mathews' framework, entry to networks and alliances is described as Integration, which is a distinctive organizational mode that complements the traditional hierarchical model of the internalization view based on transaction-cost theories.

These alternative explanations of EMNE internationalization have also been criticized. For example, Ramamurti (2012) questions whether the search for new strategic resources implies that these companies do not have ownership advantages ex ante. He suggests that 
EMNEs do possess ownership advantages, but these are different in nature from those commonly considered in the economic literature. His view is consistent with Dunning's evolving concept of ownership advantages, which takes account of the changes occurring in international markets and recognizes the existence of valuable ownership advantages in some EMNEs (Dunning et al. 1998). In the next section, we review the literature on the different types of ownership advantages attributed to EMNEs.

\section{EMNES ADVANTAGES}

The literature mostly agrees that there is a significant difference between the sets of competitive advantages possessed by EMNEs and AMNEs. Multinationals from advanced countries are most likely to possess advantages based on ownership of key assets, such as technologies, brands and other intellectual property, while EMNEs rely more on advantages related to their production capabilities, their home country social networks (such as Chinese guanxi networks) and the availability of capital (UNCTAD 2006). Ramamurti (2008) suggests that these differences in advantages may be also due to the different stages of their evolution: the advantages enjoyed by AMNEs are stronger because they have had more time to accumulate capabilities, while we can expect EMNEs to augment their ownership advantages over time, thereby reducing the gap with AMNEs (Lessard and Lucea 2009).

In the following sections we review the literature on EMNEs' country-specific advantages (CSA), such as natural resource endowments, availability of cheap factors of production, and specific cultural factors, and on firm-specific advantages (FSA) such as product or process technologies, brands, marketing and commercial skills (Rugman 2007).

\subsection{Country-specific advantages (CSAs)}

A typical home CSA for EMNEs is the ownership of low cost production factors (Lall and Chen, 1983), such as low labour costs, one of the main factors of competitive advantage for countries with a relative abundance of labour, as well as other factors such as capital. EMNEs often operate in imperfect domestic capital markets and are 
able to rely on easier and cheaper access to capital and, in some cases, cheap access to natural resources (e.g. Brazil and Russia) (Boston Consulting Group 2006).

Strong home CSAs may prevent EMNEs from transferring their (labour-intensive) activities abroad to avoid the undesirable "hollowing-out" effect in the home market. Thus, EMNE internationalization is not aimed at relocating existing activities, but rather at complementing or extending them. Accordingly, in a study of 20 Latin American MNEs, Cuervo-Cazurra (2007) finds that firms with strong CSAs are most likely to keep their production activities at home and establish marketing subsidiaries abroad.

Another relevant source of CSA is represented by the characteristics of the home country market and the relative market power of home market domestic firms. Some emerging markets are among the largest and the fastest growing markets worldwide which provides domestic firms with the opportunity to build competitive advantages by facing international competitors in their home markets (an extensive literature review on this point is provided in Contractor 2013). In an analysis of FDIs by transition economies, Andreff (2003) finds that the monopolistic or oligopolistic position of firms at home acts as a springboard to investment abroad, particularly towards countries at similar stages of development. Also, Barnard (2008) shows that EMNEs concentrate their M\&A investments in mature, traditional industries, such as cement, steel, chemicals, beverages and processed foods, where they have accumulated capabilities over time and where - compared to AMNEs - they enjoy competitive advantages such as capital-intensive production, scale economies and assembly-based mass production. A large set of CSA, including environmental uncertainty, latecomer disadvantages and national pride, can also be key to understanding the difference between EMNEs and AMNEs (Lebedev et al. 2014).

Finally, a peculiar type of CSA enjoyed by EMNEs is the formal and informal connections they establish with domestic institutions (Goldstein and Pananond 2007; Hoskisson et al. 2013; Peng 2002; Peng et al. 2008; Tan and Meyer 2007). The role played by the government is mostly stressed in relation to Chinese MNEs, which are often SOEs supported (together with some selected private firms) by various instruments such as preferential loans, selection of international partners for joint ventures to facilitate technology transfer at home, and favourable tax regimes (Athreye and Kapur 2009; Buckley et al. 2007; 
Child and Rodrigues 2005). Yiu et al. (2007) empirically assess the rise in international venture activities of a sample of Chinese firms, including in their analysis institutional variables such as the linkages to domestic institutions (i.e. central and local government, financial institutions, trade associations, research centres) as well as the participation in business networks. On the basis of their empirical findings, they conclude that the presence of institutional ties represents outstanding ownership advantages for firms originating from countries at an early stage of development, that want to expand internationally. State support and formal and informal institutional network ties also represent a competitive resource for the international activities of domestic companies in a number of other emerging countries.

While CSAs appear to be crucial for sustaining EMNEs' internationalization, there are two aspects that need to be considered. First, some CSAs, such as those based on low cost factors, may fade over time as emerging economies' production capacity grows and relative factor abundance is increasingly exploited; second, not all home country firms are equally advantaged by CSAs (Ramamurti 2008). In order to fully exploit CSAs, companies need to possess some firm-specific advantages.

\subsection{Firm-specific advantages (FSAs)}

As highlighted in early work on multinationals from developing countries (Lall and Chen, 1983), a widely diffused FSA is the capacity to develop products suited to the special needs of customers in those markets: low cost, easy to maintain, multi-purpose, adaptable to poor quality infrastructures (e.g. the Haier washing machine, which is also used to wash vegetables in rural areas of China) (Ramamurti 2008). EMNEs are also superior to AMNEs in their capacity to adapt technologies and processes to contexts characterized by a large pool of low cost labour and limited availability of inputs.

Mathews (2006) points out that the condition of being a latecomer in global markets might represent an advantage for firms engaging in international activities. Some latecomer EMNEs' operations take a global perspective from the start, and are based on rapid catch up with technologies and best practice organizational models. These firms possess advantages in the form of early awareness of global competitive networks when planning their activities, and the 
ability to build on the resources made available through these linkages (Aykut and Goldstein 2006; OECD, 2007).

Other important FSAs include participation in global production networks and global value chains (Chen and Chen 1998; Hitt et al. 2000; Makino et al. 2002). EMNEs are often able to enter production networks based on their organizational advantages, being able to leverage the resources needed to start a more active internationalization process. More specifically, EMNEs build advantages through the adoption of innovative organizational forms and by exploiting access to the resources of other companies through their international connections (Mathews 2006).

\section{EMNES' MOTIVATIONS FOR INVESTING ABROAD}

Since 1960 when EMNEs began to expand internationally, it has been evident that their motivations differ according to the level of development of the recipient economies. Resource-seeking (particularly natural resource-seeking), market-seeking and efficiencyseeking factors are the main reasons for EMNE FDIs to other developing countries, while strategic asset-seeking motivations dominate in relation to investment in developed countries (UNCTAD 2006).

These motivations have been analyzed using different methodological approaches (e.g. case study, quantitative analysis) and focusing on how different factor endowments, both at home and abroad, influence foreign investments. In the rest of this section, we discuss the motivations underlying EMNE investments abroad and focus on a specific type of strategic asset-seeking FDI that we describe as technology-driven foreign direct investments (TFDIs). Our extensive discussion of TFDIs is warranted by its representing a major motivation for EMNEs to invest in advanced countries, and because this kind of motivation - compared to others - is relatively novel and requires closer investigation.

\subsection{Why do EMNEs invest abroad?}

Numerous studies underline the importance of natural resources to EMNEs investing abroad (Ariff and Lopez 2008; Cuervo-Cazurra 
2007; Makino et al. 2002). In the context of China, natural resource abundance in the host economies has always been one of the main motivations for investing (Ramasamy et al. 2012; Sanfilippo 2010). An interesting insight from studies on Chinese natural resources-seeking FDIs is that investments are influenced by the institutional quality of the targeted host country (Buckley et al. 2007; Cheng and Ma 2010; Cheung and Qian 2009; Kolstad and Wiig 2012). Chinese firms tend to invest in countries characterized by weak institutions because the economic rents from natural resources are more easily extracted in weak institutional environments, where local authoritarian regimes and greedy elites (Collins 2009; Keen 2003; Quer et al. 2012) allow EMNEs to negotiate business opportunities and manipulate the host environment to suit their own ends.

An increasingly important motivation for EMNE FDI is the search for strategic assets. Strategic asset seeking was recognized as a motivation for FDI in the context first of Taiwanese firms. Chen and Chen (1998) and Makino et al. (2002) highlight the role played by Taiwanese firms' FDI in establishing linkages with foreign firms and tapping into strategic resources, which are key to their successive strategies of international expansion. In a comparative study of Mexico, Poland and Romania, Hitt et al. (2000) conclude that firms from emerging countries are searching for technical capabilities and managerial know-how when signing strategic alliances with firms from developed countries. In particular, several Asian firms have acquired established firms in developed countries to build competitive advantage based on the superior resources and skills located in the host countries which are not available at home (Makino et al. 2002; Mathews 2002). Their interest in acquisitions has grown thanks to the willingness of companies in advanced countries to sell or share their technology, know-how or brands, to address their financial problems or restructuring needs. The strategic assets acquired via FDIs provide the acquiring EMNEs with reputation, and allow them to obtain and control resources and to gain access to local markets (Chung and Alcacer 2002).

If several recent studies have emphasized the importance of strategic asset seeking for Chinese MNEs, market-seeking motives are also important (Amighini and Franco 2013; Amighini et al. 2013a, 2013b; Buckley et al. 2007; Cross and Voss 2007; Liu and Tian 2008). With survey data, Lu et al. (2011) investigate the motivations for FDIs 
by private Chinese firms. Starting from the premise that no single theory can explain the pattern of FDIs by EMNEs, they empirically test hypotheses derived from three different theoretical frameworks, namely the resource-based, industry-based and institutional-based views. They find that supportive government policies are important motivators for both strategic asset and market seeking OFDIs. Firms' technology-based competitive advantages and high $\mathrm{R} \& \mathrm{D}$ intensity are motives for strategic asset-seeking OFDIs, while firms' export experience and high level of domestic industry competition favour market-seeking OFDIs.

However, the motives for EMNE FDIs differ among industries and according to $\mathrm{R} \& \mathrm{D}$ intensity: firms in technology-intensive industries are more likely to conduct strategic asset seeking FDIs in order to obtain advanced technology, acquire internationally recognized brands, and attract human capital. The importance of internationally recognized brands has been identified as one of the main drivers of the increasing presence of Chinese MNEs in the Made in Italy industry in Italy (Pietrobelli et al. 2011). Acquisitions of internationally recognized brands allow latecomers to close the gap with the leading companies by acquiring strategic assets and resources. In export-intensive sectors, gaining market access and overcoming trade barriers are important motivations for FDIs.

Finally, efficiency seeking investment is rare for EMNEs and only a few studies on Malaysia (Ariff and Lopez 2008), Taiwan (Sim and Pandian 2007) and Thailand (Pananond 2007) suggest that EMNEs may search for lower production costs due to the increasing cost of production factors in their home countries, by investing in neighbouring lower cost countries.

\subsection{EMNEs and technology-driven FDIs}

One of the most important recent trends characterizing FDIs from emerging markets is the search for technological assets. Technology-driven FDIs (TFDIs) is a recent phenomenon, which has not a universally agreed definition. However, the literature makes it clear that this concept refers to FDIs aimed at accessing advanced knowledge and capabilities, mainly available in developed countries, with the aim of improving the technological and innovative capacities of the investing firms (Chen et al. 2012; Deng 2009; Luo and Tung 
2007; Makino et al. 2002; Mathews and Zander 2007; Rui and Yip 2008). Analyses of TFDIs by EMNEs are limited and very recent and mainly address the reasons why and how EMNEs engage in this type of investments.

Several empirical studies conducted on large samples of firms find that EMNEs invest in developed countries mainly for knowledgeseeking reasons (Bertoni et al. 2013; Buckley et al. 2007). This is confirmed by case studies on well-known companies such as Haier from China and Tata from India (Duysters et al. 2009). While EMNEs traditionally (although not necessarily) have relied on mature technologies licensed from the technology leaders in the advanced economies, a more recent trend is to try to develop indigenous knowledge (Aubert 2005) and indigenous innovation (Fu et al. 2011). This requires acquisitions of financially distressed technologically advanced firms, or the establishment of foreign subsidiaries in an advanced economy to benefit from knowledge spillovers and to access highly trained human capital. Several emerging country governments are encouraging and rewarding indigenous technological efforts, publishing favourable policies such as tax incentives and financial assistance to motivate EMNEs to pursue technological developments both abroad and in their home market (Chaminade and Vang 2008; Peng 2010).

Some recent research has investigated the patterns and evolution of TFDIs in some depth. For instance, in the case of the auto components industry in India, Kumaraswamy et al. (2012) show the existence of evolving technology-seeking strategies underlying TFDIs, and identify three phases in this evolution: a transition phase (through technology licensing/collaborations and joint ventures with MNEs), a consolidation phase (by developing strong customer relationships with downstream firms), and a global integration phase (involving a strategy of knowledge creation during integration in the global value chain of the domestic industry).

Comparing the $\mathrm{R} \& \mathrm{D}$ internationalization strategies of EMNEs and AMNEs, Awate et al. (2014) find that EMNEs try to catch-up by accessing knowledge from their subsidiaries in advanced countries. However, they find that the "innovation catch-up is in general much harder and generally takes much longer than, for example, output or production catch-up" (Awate et al. 2014, pp. 17). In an analysis of a sample of 154 Chinese firms, Cui et al. (2014, pp. 499) find that "strategic asset 
seeking FDI is a critical action accelerating competitive catch-up with global leaders".

In a study of EMNEs and AMNEs specialized in the machinery industry, investing in Italy and Germany, Giuliani et al. (2014) find that more EMNE subsidiaries than AMNEs are seeking to acquire advanced technology by taking over companies in advanced economies. The authors also show that some of these EMNEs transfer knowledge to their headquarters without contributing much to innovation in the local economy (i.e. exhibit a predatory behaviour), while other EMNEs do actively engage in local innovation activities and cooperate with local firms and universities in this activity. These EMNEs build local networks that allow mutual learning processes: on the one hand, local employees, supplier firms and universities are sources of knowledge for the EMNE headquarters, and on the other hand, these local actors learn from new perspectives and experience in emerging economy markets, brought by the investors. Hence, this type of cooperation is perceived as a win-win situation for both the EMNE and for the local actors, rather than a take-and-run exploitation of local knowledge by the foreign investor.

\section{CONCLUSIONS}

The rapid, global increase of EMNE FDIs is resulted in an urgent need to understand the characteristics of firms undertaking them, their drivers and, especially, their consequences. The differences between EMNEs and AMNEs have sparked a lively, and on going, scholarly debate about whether existing theories about multinationals are sufficient to understand EMNEs or whether some additional theoretical thinking is needed.

This literature review offers an updated overview of the main contributions related to EMNEs' specificities, and their differences from AMNEs in terms of advantages and motivations. We have discussed how EMNEs may differ from AMNEs: for instance, their home CSAs as well as their FSAs are profoundly different as are EMNEs' internationalization patterns. While these differences are important, the purpose of this paper is not to enter the theoretical debate on the appropriateness of the existing theories for explaining EMNEs. We have pointed out that the peculiarities of EMNEs may 
fade over time and, therefore, the fact of being an EMNE may be a contingency whose interpretation does not require a whole new theoretical apparatus.

However, this review highlights that most existing research explores the characteristics, drivers and motivations of FDIs from emerging economies, but almost entirely neglects the consequences of such investments. Setting a new research agenda is beyond the objectives of this review; nevertheless, we note that a valuable area for future research should address this limitation and focus specifically on the repercussions of EMNEs' investments in both the advanced and developing countries. These consequences require investigation on economic as well as socio-environmental grounds. We know very little about the impact of EMNEs on the capabilities of acquired firms, and on the productivity and export spillovers they generate in their host countries, especially if these are advanced countries (i.e. a South-North perspective). We also do not have a clear understanding of the socioenvironmental impacts that these firms might have on different host environments. Having their home in countries with weak institutional environments might mean that EMNEs run the risk of downgrading the socio-environmental standards in acquired firms in advanced countries, a possibility that should be of concern to policy makers.

With regard to the impact of EMNEs on their home countries there is also an urgent need for new empirical research to investigate whether early internationalization is leading to improved performance in the domestic industry, contributing to an upgrading of the productive structure of the home country. EMNEs are engaged in a process of learning from their internationalization activity and are gaining experience by accessing geographic and culturally distant markets. However, it is not clear whether this should be interpreted as an encouraging sign for their home economies and if they can expect large returns from increasing international presence.

The impact of EMNEs on the home and the host countries is open to empirical investigation; we anticipate that future research will focus on this area. 


\section{REFERENCES}

Amighini, A., \& Franco, C. (2013). A Sector perspective on China's outward FDI: The automotive case. China Economic Review, 27, 148-161.

Amighini, A., Rabellotti, R., \& Sanfilippo, M. (2013a). China's outward FDI: An industry-level analysis of host-country determinants. Frontiers of Economics in China, 8(3), 309-336.

Amighini, A., Rabellotti, R., \& Sanfilippo, M. (2013b). Do Chinese state-owned and private enterprises differ in their internationalisation strategies? China Economic Review, 27, 312-325.

Andreff, W. (2003). The newly emerging TNCs from economies in transition: A comparison with Third World outward FDI. Transnational Corporations, 12(2), $73-118$.

Ariff, M., \& Lopez, G.P. (2008). Outward FDI flow from Southeast Asia: The Malaysian experience. In R.S. Rajan, R. Kumar, \& N. Virgill (Eds.), New Dimensions of Economic Globalization. Hackensack: World Scientific.

Athreye, S., \& Kapur S. (2009). Introduction: The internationalization of Chinese and Indian firms - Trends, motivations and strategy. Industrial and Corporate Change, 18(2), 209-221.

Aubert, J.E. (2005). Promoting Innovation in Developing Countries: A Conceptual Framework. World Bank Working Paper: 3554, Washington: The World Bank.

Aulakh, P.S. (2007). Emerging multinationals from developing economies: Motivations, paths and performance. Journal of International Management, 13(3), 235-240.

Awate, S., Larsen, M.M., \& Mudambi, R. (2014). Accessing vs sourcing knowledge: A comparative study of R\&D internationalization between emerging and advanced economy firms. Journal of International Business Studies, 46:1, 63-86.

Aykut, D., \& Goldstein, A. (2006). Developing country multinationals: South-South investment comes of age. OECD Development Centre Working Paper 257.

Barnard, H. (2008). Capability development and the geographic destination of outbound FDI by developing country firms. International Journal of Technology and Globalisation, 4(1), 39-55.

Bertoni, F., Elia, S., \& Rabbiosi, L. (2013). Outward FDI from the BRICS: Trends and patters of acquisitions in advanced countries. In M.A. Marinov, \& S.T. Marinova (Eds.), Emerging economies and firms in the global crisis. Basingstoke: Palgrave Macmillan.

Boston Consulting Group. (2006). The new global challengers. How 100 top companies from rapidly developing economies are changing the world. Boston, MA: The Boston Consulting Group Report.

Buckley, P.J., Clegg, J., Cross, A.R., Liu, X., Voss, H., \& Zheng, P. (2007). The determinants of Chinese outward foreign direct investment. Journal of International Business Studies, 38 (4), 499- 518.

Cantwell, J.A., Barnard, H. (2008). Do firms from emerging markets have to invest abroad? Outward FDI and the competitiveness of firms. In K.P. Sauvant (Ed.), 
The rise of transnational corporations from emerging markets - Threats or opportunity? Cheltenham: Edward Elgar.

Chaminade, C., \& Vang, J. (2008). Globalisation of knowledge production and regional innovation policy: Supporting specialized hubs in developing countries. Research Policy, 37(10), 1684-1696.

Chen, H.M., \& Chen, T.J. (1998). Network linkage and location choice in foreign direct investment. Journal of International Business Studies, 29(3), 445-468.

Chen, V.Z., Li, J., \& Shapiro, D.M. (2012). International reverse spillover effects on parent firms: Evidences from emerging-market MNEs in developed markets. European Management Journal, 30 (3), 204-218.

Cheng, L.K., \& Ma, Z. (2010). China's outward foreign direct investment. In R.C. Feenstra, \& W. Shang-Jin (Eds.), China's growing role in world trade. Chicago, IL: University of Chicago Press.

Cheung, Y.W., \& Qian, X.W. (2009). The empirics of China's outward direct investment. Pacific Economic Review, 14 (3), 312-341.

Child, J., \& Rodrigues, S.B. (2005). The internationalization of Chinese firms: A case for theoretical extension? Management and Organization Review, 1(3), 381-410.

Chung, W., \& Alcacer, J. (2002). Knowledge seeking and location choice of foreign direct investment in the United States. Management Science, 48(12), 1534-1554.

Collins, D. (2009). The failure of a socially responsive gold mining MNC in El Salvador: Ramifications of NGO mistrust. Journal of Business Ethics, 88(2), 245-68.

Contractor, F.J. (2013). Punching above their weight. International Journal of Emerging Markets, 8(4), 304-328.

Cross, A.R., \& Voss, H. (2007). Chinese investments in the United Kingdom: An assessment of motivations and competitiveness. Paper presented at the Conference of Internationalisation of Chinese and Indian firms, Uxbridge, UK, 18-19 April.

Cuervo-Cazurra, A. (2007). Sequence of value-added activities in the internationalization of developing country MNEs. Journal of International Management, 13(3), 258-277.

Cui, L., Meyer, K.E., \& Hu, H.W. (2014). What drives firms' intent to seek strategic assets by foreign direct investment? A study of emerging economy firms. Journal of World Business, 49(4), 488-501.

Deng, P. (2009). Why do Chinese firms tend to acquire strategic assets in international expansion? Journal of World Business, 44(1), 74-84.

Dunning, J.H. (1981). Explaining the international direct investment position of countries: Toward a dynamic or development approach. Review of World Economics, 117(1), 30-64.

Dunning, J.H. (1995). Reappraising the eclectic model in an age of alliance capitalism. Journal of International Business Studies, 26(3), 461-491.

Dunning, J.H. (1998). Multinational enterprises and the global economy. Wokingham: Addison Wesley.

Dunning, J.H. (2006). Towards a new paradigm of development: Implications for the determinants of international business. Transnational Corporations, 15(1), 173- 
227.

Dunning, J.H., \& Lundan, S.M. (2008). Institutions and the OLI paradigm of the multinational enterprise. Asia Pacific Journal of Management, 25(4), 573-593.

Dunning, J.H., van Hoesel, R., \& Narula, R. (1998). Third world multinationals revisited: New developments and theoretical implications. In J.H. Dunning (Ed.), Globalisation, trade, and foreign direct investment. Cheltenham: Elsevier.

Dunning, J.H., \& Wymbs, C. (1999). The geographical sourcing of technology-based assets by multinational enterprises. In D. Archibugi, J. Howells, \& J. Michie (Eds.), Innovation policy in a global economy. Cambridge, U.K: Cambridge University Press.

Duysters, G., Jacob, J., Lemmens, C., \& Jintian, Y. (2009). Internationalization and technological catching up of emerging multinationals: A comparative case study of China's Haier Group. Industrial and Corporate Change, 18(2), 325-349.

Fu, X., Pietrobelli, C., \& Soete, L. (2011). The role of foreign technology and indigenous innovation in the emerging economies: Technological change and catching-up. World Development, 39(7), 1204-1212.

Giuliani, E., Gorgoni, S., Günther, C. \& Rabellotti, R. (2014). Emerging versus advanced country MNEs investing in Europe: A typology of subsidiary globallocal connections. International Business Review, 23(4), 680-691.

Goldstein, A., \& Pananond, P. (2007). Singapore and Thailand. Paper presented at the International Workshop on Intra-Asian FDI Flows: Magnitude, Trends, Prospects and Policy Implications, India Habitat Centre, New Delhi, 25- 26 April.

Hitt, M.A., Dacin, M.T., Levitas, E., Arregle, J.L., \& Borza, A. (2000). Partner selection in emerging and developed market contexts: Resource-based and organizational learning perspective. Academy of Management Journal, 43(3), 449-467.

Hoskisson, R.E., Wright, M., Filatotchev, I., \& Peng, M.W. (2013). Emerging multinationals from mid range economies: The influence of institutions and factor markets. Journal of Management Studies, 50(7), 1295-1321.

Keen, D. (2003). Greedy elites, dwindling resources, alienated youths: The anatomy of protracted violence in Sierra Leone. International Politics and Society, 2, 321360.

Kolstad, I., \& Wiig, A. (2012). What determines Chinese outward FDI? Journal of World Business, 47 (1), 26-34.

Kumar, N. (1998). Emerging outward foreign direct investment from Asian developing countries: prospects and implications, globalization, foreign direct investment and technology transfers. London: Routledge.

Kumar, K., \& McLeod, M.G. 1981. Multinationals from developing countries. New York: Free Press.

Kumaraswamy, A., Mudambi, R., Saranga, H., \& Tripathy, A. (2012). Catch-up strategies in the Indian auto components industry: Domestic firms' responses to market liberalization. Journal of International Business Studies, 43 (4), 368-395.

Lall, S., \& Chen, E. (1983). The new multinationals: The spread of third world enterprises. Chichester: Wiley.

Lebedev, S., Peng, M.W., Xie, E. \& Stevens, C.E. (2014). "Mergers and acquisitions in 
and out of emerging economies." Journal of World Business (forthcoming). Lessard, D., \& Lucea, R. (2009). Mexican multinationals: Insights from CEMEX. In R. Ramamurti, \& J.V. Singh (Eds.), Emerging multinationals from emerging markets. Cambridge, U.K: Cambridge University Press.

Li, P.P. (2007). Toward an integrated theory of multinational evolution: The evidence of Chinese multinational enterprises as latecomers. Journal of International Management, 13(3), 296-318.

Liu, L., \& Tian, Y. (2008). The internationalisation of Chinese enterprises: The analysis of the UK case. International Journal of Technology and Globalization, 4(1), 87-102.

Luo, Y., \& Tung, R.L. (2007). International expansion of emerging market enterprises: A springboard perspective. Journal of International Business Studies, 38(4), 481498.

Lu, J., Liu, X., \& Wang, H. (2011). Motives for outward FDI of Chinese private firms: Firm resources, industry dynamics, and government policies. Management and Organization Review, 7(2), 223-248.

Makino, S., Lau, C.M., \& Yeh, R.S. (2002). Asset-exploitation versus asset seeking: Implication for location choice of foreign direct investment from newly industrialized economies. Journal of International Business Studies, 33(3), 403421.

Mathews, J.A. (2002). Dragon multinational - A new model for global growth. Oxford and New York: Oxford University Press.

Mathews, J.A. (2006). Catch-up strategies and the latecomer effect in industrial development. New Political Economy, 11(3), 313-335.

Mathews, J.A., \& Zander, I. (2007). The international entrepreneurial dynamics of accelerated internationalisation. Journal of International Business Studies, 38 (3), 387-403.

Narula, R. (2006). Globalization, new ecologies, new zoologies, and the purported death of the eclectic paradigm. Asia Pacific Journal of Management, 23(2), 143151.

OECD. (2007). Business for Development - Fostering the Private Sector. Paris: OECD.

Pananond, P. (2007). The changing dynamics of Thai multinationals after the Asian economic crisis. Journal of International Management, 13(3), 356-75.

Peng, H. (2010). China's indigenous innovation policy and its effect on foreign intellectual property rights holders. King \& Wood's IP Department China Law Insight Working Paper.

Peng, M.K. (2002). Towards and institution- based view of business strategy. Asia Pacific Journal of Management, 19 (2), 251- 267.

Peng, M.K., Wang, D.Y.L., \& Jiang Y. (2008). An institution-based view of international business strategy: A focus on emerging economies. Journal of International Business Studies, 39 (5), 920- 936.

Pietrobelli, C., Sanfilippo, M., \& Rabellotti, R. (2011). The "Marco Polo" effect: Chinese FDI in Italy. International Journal of Technology and Globalization, 4(4), 277-291.

Quer, D., Claver, E., \& Rienda, L. (2012). Political risk, cultural distance, and outward 
foreign direct investment: Empirical evidence from large Chinese firms. Asia Pacific journal of management, 29(4), 1089-1104.

Ramamurti, R. (2008). What have we learned about emerging market MNEs? Cambridge, U.K: Cambridge University Press.

Ramamurti, R. (2012). What is really different about emerging market multinationals? Global Strategy Journal, 2(1), 41-47.

Ramasamy, B., Yeung, M., \& Laforet, S. (2012). China's outward foreign direct investment: Location choice and firm ownership. Journal of World Business, $47(1), 17-25$.

Rasiah, R., \& Gammeltoft, P. (2009). Outward foreign direct investment from emerging economies: Trends, drivers and firm-driven home government policies. Paper presented at the $7^{\text {th }}$ Globelics International Conference, Dakar, 6-8 October.

Rugman, A. (2007). Multinational enterprises from emerging markets. Paper presented at the Berlin Roundtable meeting on the Role of the G8 in an Endangered Global Economic and Political Climate, Berlin, 1-2 June.

Rugman, A.M., \& Doh, J. (2008). Multinationals and development. New Haven: Yale University Press.

Rui, H., \& Yip, G.S. (2008). Foreign acquisitions by Chinese firms: A strategic intent perspective. Journal of World Business, 43(2), 213-26.

Sanfilippo, M. (2010). Chinese FDI to Africa: What is the nexus with foreign economic cooperation? African Development Review, 22(S1), 599-614.

Sim, A.B., \& Pandian, J.R. (2007). An exploratory study of internationalization strategies of Malaysian and Taiwanese firms. International Journal of Emerging Markets, 2(3), 252-273.

Tan, D., \& Meyer, K.E. (2007). The scope of business groups: A Penrosian analysis. SSRN working paper. http://papers.ssrn.com/sol3/papers.cfm?abstract_id=1013389. Accessed 10 March 2013.

Teece, D.J., Pisano, G., \& Shuen, A. (1997). Dynamic capabilities and strategic management. Strategic Management Journal, 18(7), 509-533.

Tolentino, P.E. (1993). Technological innovation and third world multinationals. London: Routledge.

UNCTAD. (2005). World Investment Report 2005: Transnational corporations and the internationalization of RED. New York and Geneva: United Nations Conference for Trade and Development.

UNCTAD. (2006). World Investment Report 2006: FDI from developing and transition economies: Implications for development.. New York and Geneva: United Nations Conference for Trade and Development.

UNCTAD. (2015). World Investment Report 2015: Reforming International Investment Governance. New York and Geneva: United Nations Conference for Trade and Development.

Yiu, D.W., Lau, C.M., \& Bruton, G.D. (2007). International venturing by emerging economy firms: The effects of firm capabilities, home country networks, and corporate entrepreneurship. Journal of International Business Studies, 38 (4), 519-540. 
